\title{
Saratanya (House Servant) in Ethiopia and 'Ya'yan Magajiya (Errand Children) in Nigeria
}

Mailafiya Aruwa Filaba,

\section{Abstract}

Saratanya is the name for House Servant all over Ethiopia, whereas 'Ya'yan Magajiya is the nomenclature for servants of Matrons operating canteens and brothels in Nigeria. The servants in these systems are exploited by their employers and most often treated as if they are slaves. In addition to labour exploitation, the systems are conduits for commercial sex networking, drug pushing and human trafficking. Earlier studies attributed the systems to poverty. It is argued that at this age of recognition of fundamental human rights, both the community leaders and the governments should ensure that the fundamental human rights of servants are observed by their employers.

\section{Introduction}

A study was conducted to examine the nature of Saratanya or house-help/servant custom in Jimma town in time perspective. The 'Ya'yan Magajiya or Matron's servants culture in Nigeria is analysed here and compared with the saratanya servitude in Ethiopia, and located the practices within national poverty. There are recommendations that may lead to the safeguardof the fundamental human rights of house servants. 
The Saratanya custom in Jimma town is pervasive as with others in Ethiopia. The drive for Saratanya in Jimma is so high so much that even the literally poor individuals and students who can barely feed themselves employ one or two Saratanyas. The saratanya themselves opt for the institution in plea of poverty or broken homes. A few were forced in to the institution by their guardians. The implications are obvious as some people abuse the institution by utilizing it in the negative extreme and treating their Saratanyas as if they are slaves, while others utilize the institution as avenue for human trafficking and forcing girls into commercial sex. The use of saratanya in the extreme is informed by the antecedent that the community was used to slavery and slave trade, and female trafficking is still going on in the region.

Similarly, in Nigeria, some children are influenced or forced to go and serve in brothels or canteens and their magajiya (matrons) exploit them. Their services are scorned at as deviation from community norms, as some of them are engage in crimes.

\section{Methods}

The survey of Saratanya system was conducted in Jimma town between November 2006 to March 2007, using the methods of In Depth Interviews, Group Discussions and Observation. There were interviews and discussion with 30 Saratanyas and 10 getas (masters) respectively got through purposive sampling. There was also trail of the deports (delallabets) where Saratanyas are acquired for observation and discussion with the proprietors, and interviews were conducted in four most popular ones around the makerto (market). Inferences were drawn from earlier studies on the 'Ya'yan Magajiya, which inferences were used to discuss the cultural and socio-economic dynamics informing the two systems of exploitation of labour. 


\section{The Data/Results}

Saratanya (House Help) Contract in Jimma Town: House servant in Jimma is called Saratanya, and they call it in English 'House-help.' House-help contract is the arrangement for paid domestic services. The practice is widespread all over East Africa, Middle East and the Far East. In Jimma town, the contract largely involves intermediaries although there are few cases of direct negotiation between the Saratanya and the bidder. The wage does not commensurate the type of the labour/services they render. However, as from 2005, the expatriates who did not want 24 hours service negotiated for the hours and the nature of the domestic work the saratanya would do. The wages paid by the expatriates is twice or thrice more than the amount the indigenes pay their Saratanyas for similar work.

There are depots called Dallalabet or Bunnabat where the unemployed saratanya-to-be wait for employers. Few of them are often seen waiting there to be engaged. Similarly, some Mishits (night clubs) and hotels are areas where the would-be-saratanya unemployed loiter around to attract geta (masters/mistresses). Hence some bidders could ask the hoteliers to contact one. Ten years back, one needed to register with ETB1 (One Ethiopian Birr) with the brokers (belleh) before one was allowed to pick one saratanya. By 2005, the fee had risen to ETB 20. By 2006 it reached ETB 120. As from five years back, the brokers started to become crafty by ensuring that the saratanya stay and work for them for some prescribed days before they are given out to bidders.

There are about 10 Dellalabets located at various parts of Jimma, but the most popular Dellalabets are those located at different corners of Jimma market. They are all run by men, 
Saratanya in Ethiopia \& 'Ya'yan Magajïya in Nigeria

and mainly as individual or family guilds. Four most popular ones in the market were visited, and they claimed not to have any network, but that the unemployed wishfully go there to be linked to a geta. They are all in the middle of rented shops. They look like shops as some petty trading and crafts are going on there. The patronizers come from anywhere. Operators of Dellalabets do not care about the background of the would-be-sarantaya neither the bidders. The Dellalabets have simple arrangement of furniture: the business table and chair for the belleh also called dellalah (dealer); a chair for the bidder; table for the unemployed to sit awaiting bidder; canter containing crafts and tools; space for coffee/tee brewing and so on. A desk is kept outside for the unemployed as window advert. No receipt or log book is kept. They do not pay taxes for operating human trafficking and operating the dellalabets but for the little craft going on in the shop. The negotiation is very simple: One chooses any of the unemployed considering the physical and/or experience/skill aptitude. The bidder pays the fixed amount for consultation, and the saratanya also pays the fixed amount to the belleh for arranging the contact and for staying there. Since three years back, the amount was 2 to ten birr. By 2006 it had risen to 50 to 120 birr.

Females - girls and divorced of ages of 15 to 30 constitute about $80 \%$ of the unemployed in the dellalabeth in Jimma. Almost all of them never had primary school education. They claimed to have come from rural areas in Jimma environs. The rest $20 \%$ are the urban poor males of ages of 13 to 35. Almost all of them attempted primary school education. The male unemployed easily get short-time contracts like carriers and cleaners. Most of them alleged that they had lost their jobs with former geta. While at the dellalabet, they feed themselves. If they get into trouble, the owner of the Dellalabet intervenes. Most of the Saratanya working with expatriates were linked to their geta through 
friends who are Saratanya, and almost all of them were attending school by 2006, as the expatriates are interested in their development. Very few indigenous geta allow their Saratanya to attend school. About $30 \%$ of Saratanyas had children out of wed-lock and became school drop outs. $1 \%$ of Saratanyas are married and live with their families after working hours.

The Saratanyas are mostly rural female immigrants. Substantial number is derived from the urban poor, commercial sex workers, street children and refugees. Most of them allege that they are orphans! Almost every house in Jimma irrespective of status, have one or two Saratanyas. Over $90 \%$ of Saratanyas all over Ethiopia are females. Males are rarely employed on permanent basis as they do not bear oppression for too long, they are mobile as they know two or more different professions, they easily migrate to greener pastures, they are not harassed as women are, and most of the domestics are culturally reserves for females. Males are employed mainly by professionals and large households where there is need for clearing the grass, dredging, animal husbandry, crafts, washing of large clothes, etc.

Since time immemorial the saratanya stayed in the master's house. About five years back, some geta - mostly expatriates - did not want their Saratanyas to be sleeping in their houses and therefore encouraged them to be coming from their homes. Since then Saratanyas started to prefer staying on their own and come to work only in the day time. Saratanya should be categorized: those staying with their masters, those sleeping elsewhere - friends or relatives or their own hired rooms, and those with more than a master. By 2006, almost all the saratanya with indigenous geta stayed 
Saratanya in Ethiopia \& 'Ya'yan Magajïya in Nigeria

with them, whereas almost all the saratanya with expatriates came from their homes to work. Only those with the expatriates had chance to engage two or more get and they constituted about $2 \%$. It seems some of them preferred staying with a relative or friend in order to scheme for other means of livelihood, like sporadic services in the groceries, coffee room, hotels, retails and so on. Indeed, they engaged in clandestine commercial sex work. With increased high cadre employees in Jimma University, some of them secured two to three masters, serving them at agreed hours or days. Through observation and estimation of informants, by 2006, almost all expatriates had saratanya. Almost all - about 97\% government employed and the retired had saratanya. All the high and middle/professional class houses had saratanya. 60 $\%$ of the low-income and peasant houses had saratanya. Those poor that had no saratanya were those with large girls in the house and some broken homes.

The responsibilities of Saratanya in Jimma included the following:

Washing of utensils

Washing of clothes

Grinding and brewing

Coffee/Tea

Dressing bed

Baking

Itinerary

Sweeping and mopping the floor

Baby care

Messenger

Shoes cleaning

Arranging items of rooms
Dressing/Making up the geta (master/mistress);

Errand/shopping

Farming

Watering flower bed

Cleaning and arranging shops

Fuel wood collection and

hewing

Water Fetching

Hair/Head dressing

Sewing

Security/Night Guard

Taking children to school 
Serving visitors

House building

maintenance/repairing/

plastering/building
Cleaning the church/mosque Animal husbandry/feeding or grazing dogs/ cats/goats/ donkeys/horses/cows

\section{Extreme Services and Relations}

Almost all the respondents complained that Saratanyas were used in the extreme in many ways. The commonest was overstretching with work throughout without rest. Other extreme services even some neighbours looked at with contempt included: Romancing and Sex; Massaging; Concubinage; Forced to commercial sex with visitors; trafficking and sold out to strangers; Feeding the master;

Criminal assignment; Failure to keep to terms of contracts like prompt and commensurate payment of wages; and so on. There were reported cases of raping. Out of the thirty Saratanyas interviewed, five indicated that they were once raped by their getas, 20 of them claimed that there were unsuccessful sex advances by their getas, while the rest 5 claimed they had never been sexually harassed by their geta. The raping and sexual advances all came from unmarried getas. All the respondents reported that they knew of many rape cases. They also made it known that some Saratanyas made sexual advances to their getas. Some Saratanyas who had sexual relations with their geta ended up marrying them particularly when they got pregnant. There were cases of village teachers marrying their Saratanyas. There was no case of a geta impregnating a saratanya without marrying her in the end.

Saratanya in Ethiopia \& 'Ya'yan Magajiya in Nigeria

With the new practice of the saratanya not staying permanently with the geta, some of the geta restricted their 
Saratanya in Ethiopia \& 'Ya'yan Magajiya in Nigeria

meals, and sometimes refused them food on the ground that they should eat from their houses. This included denial of Saratanya's personal use of essential goods in the house, like detergents, water, etc. Many getas did not dress their saratanya. Whenever they did so, it was simply giving them worn out clothes. They were not attended to like the children of the house. In other words, the outfits of the saratanya were inferior to those of the house members.

Many getas did not allow their Saratanyas to attend church activities or played outside with mates. Their movements were strictly restricted, including with whom to talk to or communicate with. No geta ever allowed his/her saratanya to bring her boy-friend into the house. Saratanya was not to sleep on the same bed with the children in the house even though they played together unless during weaning the child or the child was disturbing the mother. Some houses had different serving dishes and cups - normally inferior - for their saratanya. Many of the indigenous geta were harsh and could corporally punish their Saratanyas whenever they went wrong.

\section{Remunerations and wages of Saratanyas:}

Remuneration of Saratanya was not uniform all over the town, as each geta determined the nature of the remuneration/wages. With the new system of bargaining, the Saratanya argued that her friends were paid this or that amount, while the geta insisted that she took whatever offer or leave. Ten years ago there was no wages and there was no difference between a Saratanya and a slave. The geta remunerated the saratanya with feeding, scarce dressing and space for sleeping. Issue of wages in Jimma came with arrival of expatriates whom the society looked upon for subsistence. The indigenes reluctantly wanted to pay wages to their 
Saratanyas and saw them as literally not different from proper slaves.

With the coming of expatriates, few top class getas started to emulate them, fixing days or hours of work. Some mission houses/Churches had as many as ten Saratanyas who worked on shifting basis and were paid per hours of work. Some of them paid for extra hours put in by the saratanya. The church compounds did not like noise, and so no saratanya talked anyhow there. The mission houses involved their Saratanyas in the prayer sessions. The expatriates started to pay 100 birr per month five years ago. By the end of June 2006 all expatriates paid between 100 to 200 birr per month, while the indigenes paid between 40 to 60 birr per month.

\section{Similarity of 'Ya'yan Magajiya in Nigeria to Saratanya in Ethiopia}

The Magajiya system is a special form of slavery, commercial sex and women trafficking conduit in Northern Nigeria, where the Magajiya - the entrepreneurial matron similar to the dellalah/dellalabet 'recruits' and tutors young women to provide mainly commercial sex. Gidan Magajiya or gidajen kashe ahu - are well known local brothels also rendering catering, drinking and renting services mostly in truck transit camps. Magajiya system has well-defined market and roles for participants. It has suppliers, investors (the Magajiya - the matron), 'workers' (trafficked women); and the middlemen (the Magajiyas and 'Dandaudus). The patronizers/customers are mostly the drivers, while any man interested may have access. (Umaru, 2006). Magajiya system has acquired legitimacy and social approbation through the processes of 'aculturization' and 'layering'. Acculturation is a 
form of a-tuned common cultural practices of the people like courtship, which magajiya system pretends to provide as cover for commercial sex and trafficking, and therefore having a quality of 'invisibility' (Hynes and Raymond (2002). Layering is the process of operating an official business venture in order to legitimize itself like retail food and beverages' businesses at truckers' transit camps. They launder the huge proceeds from commercial sex and trafficking into legitimate business such as local and trans-border textile and jewelry merchandizing, purchase of land and movable assets such as commercial building or estates and commercial vehicles. Magajiya system operates through either Single Matron - Client link whereby the Magajiya single-handedly scouts and transports the young women to the operational sites from rural areas and urban slums on promise of better life, and through Multiple Matron Client links whereby the system has a network-links with 'Yandaudu (male food sellers), 'Yan Achaba (commercial cyclists) and 'Yan Kamashu (Garage touts) acting as contactpoints to stranded 'run-aways' or free-hiking young fortuneseekers. Some of the major factors some women alleged drew them into the system include poverty, unemployment, huge profits, and search for better life in the town. Some of them alleged that they were escaping from forced marriage, the local practice of 'Ya'yan goyo (child adoption) or the system of foster parenting, and dysfunctional family pressure.

Once these young women are under her care, the Magajiya provides them with food, accommodation, jobs, drugs, other commodities or intangibles such as approval and care. In the normal course of their official work (assisting the Matrons in her shop or restaurant), they advertently showcase their 'wares' to potential male patrons who, in most cases, are regular or guest customers of the Magajiyd's joint. In addition to settling the provider of sexual services, the client pays another fee imposed by the Magajiya, and the amount of the 
fee depends on their familiarity and his past generosity. Some matrons do not remunerate their wards and only allow them to cater for themselves through the proceeds of their trade. Some matrons get a share of the proceeds from their workers after every outing. Some Magajiya subcontract intermediary roles to their favoured pimps who operate within or outside their territory.

The larger net-working of magajiya system is its link with international trafficking and slave trading across Africa and beyond, mainly trafficking women for commercial sex. (U.S. State Department Trafficking in Persons Report, June 2003; Aita, 2004; Hynes and Raymond, 2002: 197; Aghatise, 2004: 1126; Cannon et. al., 2006; Farley, 2004) The United Nations (UN) defined 'trafficking in persons"thus:

the recruitment, transportation, transfer, harbouring or receipt of persons, by means of the threat or use of force or other forms of coercion, of abduction, of fraud, of deception, of the abuse of power or of a position of vulnerability or of the giving or receiving of payments or benefits to achieve the consent of a person having control over another person, for the purpose of exploitation.

Exploitation shall include, at a minimum, the exploitation of the prostitution of others or other forms of sexual exploitation, forced labour, or service, slavery or practices similar to slavery, servitude or the removal of organs. (Agbu, 2003;

(http://www.unicef.org/protection/index exploita tion.html?=printme) 
Saratanya in Ethiopia \& 'Ya'yan Magajiya in Nigeria

\section{Discussions}

\section{Transformation and abolition of Slavery in Africa}

House-help has always been a desideratum for those who need more labour, leisure, exploitation of others, large family and so on. Master-Servant relation is as old as civilization and practiced in both primitive and civilized societies. Each civilization and master defined the status of servants. In other words, the terms of contract vary from civilization to another and from master to another. Indeed, the social mode of production of the society and the status of the master to some extent inform the nature of the masterservant relation.

There has been noticeable gradual transformation of the master-servant relations over the civilizations, by gradual liberalization, recognition of certain rights of servants, increased remunerations and legal proscription. In Africa generally, there was hardly any difference between a servant and a slave before the British and French colonial conquests, while the Portuguese and German colonies intensified slavery. However, even in the French and British colonies, Africans were treated as colonized, which had the stigma similar to slavery but with right to life and property. The British and French colonial rules forcibly stopped the practice of traditional slavery by 1937 (Lovejoy 1983; Lovejoy and Hogendorn 1997). Slavery then started to transform into master-servant (colonizer-colonized) relations of unequal exchange of materials and underpaid labour of the colonized and underpriced products of the colonized. In order to liberate slaves ready for chap and free movement of labour and articles, all individuals were to be free and only have master-servant contract whereby the contract could be terminated either by the master or the servant any time and the servant could have right to own self, own properties, marry, and so on. This 
is unlike in the slavery institution where these rights are denied the slave.

It should be noted that long before the colonial conquest, slavery among some communities was undergoing transformation. Across civilizations, servants who joined the army were immediately accorded more rights than those servants and slaves who did not and were accorded full citizenship of those communities and some of them even became community leaders with immense leadership responsibilities. With increased realization of some rights, enforcement of United Nations' laws against slavery, exposure and globalization, slavery is gradually metamorphosing into contract institution in towns.

Saratanya institution is evidently a continuation of slavery. In deed, the concepts 'slavery' and 'house-help' have same meaning - Saratanya, and the modern saratanya do not want to be addressed as 'saratanya' but insinuating references like 'assistance', 'help,' etc. Since slavery is legally and morally outlawed, no geta can sell out or purchase saratanya. The relationship is contracted or negotiated and the saratanya or geta can wishfully terminate the contract.

Servitude of any nature is perceived to connote the following: Condition of being enslaved, or under bondage; state of subjection to an owner or master or forced labor imposed as punishment; lack of personal freedom, as to act as one chooses; a condition in which an individual lacks liberty especially to determine his or her course of action or way of life; the state of being a slave. However, some servants could be intellectuals who work under masters or business in order to earn what with to sponsor education, and therefore not in state of being a slave (Internet dictionaries 2007) 
Saratanya in Ethiopia \& 'Ya'yan Magajiya in Nigeria

\section{Urbanization and Urban cum Rural Poverty informing Saratanya institution}

Almost all the servants interviewed during this survey extenuated that poverty in their houses pushed them to opt for saratanya as survival strategy, while all the masters who were interviewed maintained that the custom here reserves domestics for females and are employed as servants.

Perhaps, with the evolution of the middle class, expansion in the economy and the rapid urbanization whereby the urbanites leave their houses to work or trade elsewhere, they need housekeepers/helps. Congruously, too, poverty in the rural Ethiopia pushes some youth into the towns with the view to earning better living. They soon become the unemployed army readily available as saratanya. How this operates in Jimma town will be elaborately discussed. There will be allusions to similar phenomena in Africa in the course of discussion.

It is worthwhile defining poverty in order to understand how it correlates to the saratanya institution. There are definitions of poverty that point to the fact that rural and urban poverty inform the master-servant contract to a great extent, like the saratanya institution.

The poverty stricken people or country are in lack of a wide range of economic and other resources like deprivation of essential goods and services - food, clothing, shelter and healthcare. Scholars have different measurements of poverty: Absolute or Objective poverty refers to a set standard which is consistent over time and between countries, measuring the percentage of the population eating less food than is required to sustain the human body (approximately 2000-2500 kilocalories per day), and therefore applies to people with the lowest incomes and whose per-capita food supplies are less than 2,200 calories per day, the least education, the lowest 
social status, the fewest opportunities with little or no electronics and means of communications, low live expectancy because of prevalence of diseases, and high child mortality rate. The World Bank defines extreme poverty as living on less than US\$ 1 per day, and moderate poverty as less than $\$ 2$ a day. The population living in extreme economic poverty is mostly in the developing world and Ethiopia is on the top list. Absolute poverty measures exclusively the well-being of the poor. Absolute poverty is the situation when individuals or households are not able to acquire a specific level of consumption, the minimum food stuff baskets to provide their minimum needed calories. Thus, absolute measurement focuses on the standard of living measure and the poverty line. Some scholars analyze poverty in relative terms dependent on social context since the number of people counted as poor could increase while their income rise. A relative measurement compares the total wealth of the poorest $1 / 3$ of the population with the total wealth of richest $1 \%$ of the population, and by comparing one group's situation to the situations of those who are more advantaged. Relative poverty is comparative measure of household income level to nation income level, which includes: the head count ratio incidence of poverty; the poverty gap income short fall; the disparity of income distribution measure; composite poverty measurement; physical quality of life index; augmented physical quality of life index; and the human development index. (Wikimedia Commons /Internet accessed on 4/4/7.) Poverty is judged compared to the standard of living of other in the society. Some subjective poverty measurements defined poverty as the absence of minimum resources to consume basic goods and service critical for the survival of life. It 
Saratanya in Ethiopia \& 'Ya'yan Magajïya in Nigeria

considers the options of persons with respect to their own situation as the determinants of poverty, like what individuals/household consider as good income and necessities a household should posses. Thus when the household has insufficient basic necessities and unfit housing and lack of active participation in the decision making process, is termed poor. (Anyanwu 1997; Odusola, 1997; Wikipedia Commons /Internet accessed on 4/4/7; Federal Ministry of Economic Cooperation and development 1992).

Many different factors combine to cause poverty that seem to apply to Ethiopia partially or greatly as follow: Too much government intervention and regulation in the economy; Poverty itself, preventing investment and development; Geographic factors like desert and land depletion, and lack of natural resources, which greatly apply to Ethiopia; Large dependent population (the aged and children); Wars; Inadequate property rights; Lack of education and skills; Cultural inhibitors like age, gender, racial discriminations; Lack of functioning democracy; Government policy that the middle classes is the main beneficiaries of social benefits and services, even when they are primarily targeted at the poor; Prevalence of diseases; Inadequate nutrition in childhood; Individual life styles and pathological problems like laziness, alcoholism and drug addiction; etc. (Wikimedia Commons /Internet accessed on 4/4/7.)

Other independent scholarly surveys confirm the above causes of poverty. The causes include condition of low income or low consumption and unable to meet basic material needs principally food, water, clothing, shelter, education and health (Aku, et.al;1997; Amis and Rakodi 1994; Sen 1981; Obadan 1997; Owunike 1996). Poverty also includes lacking of sufficient environmental requirements such as air, serenity, and arts, as well a lack of basic non-material needs like political and community participation, identity, dignity, and so 
on (Ajakaiye 1998; Blackwood and Lynch 1994; Streeten 1997; Hauff and Kruse, 1994; Schubert, 1994;). The politics of allocation of resources and marginalization directly and indirectly induce poverty on people in isolated rural areas who lack essential infrastructures. Government makes some persons to loose their jobs and also disable them from finding employment as a result of economic reforms under the structural adjustment programmes. Furthermore, some governments marginalize some ethnic minorities by depriving and persecuting them economically, socially, culturally and politically. (Federal Office of Statistics - FOS; CBN 1998; NES 1975, 1997; Ogwumike 1991; Ogwamike and Ekpenyong, 1996; Onah 1996; World Bank 19931996).

World Bank reports revealed that poverty in Nigeria, similar to the rest African countries, differed from one region to another and from rural to urban areas as strongly influenced by education, age, nature of employment and sex. All over African countries, women remain severely disadvantaged as a special social group in terms of unequal access and inability to get the minimum standard of living in terms of access to health, education, financial and agricultural extension services even though they play an essential and dynamic role in economic life. The report also highlighted the tendency for the poor to be concentrated in poor communities and sometimes even living under sub-human conditions. Poverty in parts is strongly linked to degrading environment and the poor compelled to unsustainably consume their natural resource base without any appreciable re-investment in the maintenance of the natural capital stock (World Bank 1996, 2003), which is similar to the situation in Pakistan 
(Ahmad, E. 1981). Therefore, poverty is the inability to attain a minimal standard of living (Afonoja and Owunike, 1996).

Regrettably, poverty is on the increase in developing countries in spite of the pursuit of economic adjustment programmes. In most cases, poverty is a reflection of glaring defects in the government economic policies like mass retrenchment, privatization, withdrawal of subsidies, low salary, mass penury/ejection without compensation, pauperization of the working lass, mass retrenchment, unemployment, poor welfare services, failing agricultural income as a result of low prices for agricultural products, failing monetary value, inflation, and so on, and in part, violent religious and ethnic conflicts, all combining to disable individuals and groups have regular flow of income for sustenance and denial of access to the basic necessities of life (Greenwald and Associates). The policy of withdrawal of agricultural subsidies' policy was directed by the World Bank in the 1980 s as a precondition for getting (Internataional Monetary Fund (IMF) loans, and the World Trade Organization has worsen the situation by lowering the prices of agricultural products from IMF recipient countries.

Some scholars stressed four basic causes of poverty as: Political mal-distribution; Capitalist craft; Individual status; and Corruption (Ale A.1975 and Tella. A.1997). The political power of the society determines the extent and distribution of poverty among the population where the ruling class is constituted by the few who establish an exploitative property and income opportunities using the state power and coercion. These causes informed theories like "the capitalized entrepreneur theory." This theory posits that the crude exploitation of the poor by means of low wages and poor conditions of service - primitive accumulation - to allow for a possible rise in savings results into inequality in income and deprivation of the lower end of society where the majority live. 
The "individual attribute theory" presumes that an individual's location in the society's hierarchy of income and wealth is largely due to his motivations, aptitudes and abilities. The "corruption theory" posits that in countries where there is high level of corruption there leads to high level of poverty.

Some scholars summarily grouped the theories into two: "case theory", which explains poverty on a micro level case-by-case basis like lack of education or skills, ill-health, old age, handicaps, race discrimination and other factors that cause poverty to individuals; and "generic theory", which focuses on the whole economy - the macro level like high rate of unemployment, lack of access to productive resources, subsistence, culture of dependency, etc. in the economy as a whole bringing about poverty. All these categories apply in Ethiopia and inform saratanya system.

\section{Conclusion}

Saratanya institution in Ethiopia is a continuation and transformation of slavery. The Saratanyas argued that they opted for the institution as their villages are poor. The magajiya system is similar to saratanya institution and other master-servant relations all over the world. Indeed, theories of poverty above seem to agree with their perception. The currently low pay of Saratanyas' wages conclusively indicates both the 'case' and 'generic' poverty - poverty at individual and national levels. Indeed, Ethiopia is rated among the poorest countries in Africa with very low Gross Domestic Product and National Income levels, and currently being sustained by AIDS and grants from Non Governmental Organizations, World Banks, Individual philanthropists, European countries and companies. 
The saratanya system is therefore a positive utilization of redundant labour and poverty alleviation in a form of caring for the under-privileged. However, there are issues of violating the fundamental human rights of the saratanya as their getas restrict their personal movements, grossly underpay them, violet the contracts, use them in the extreme and sometimes get them trafficked. Since almost all the saratanya are women, the system indicates gender inequality and deprivation encapsulated in cultural/religious /patriarchial practices.

\section{Recommendations}

The author opines that this democratic dispensation should challenge the violation of fundamental human rights and encourage Saratanya to seek for redress whenever their geta (master) violate the contract, undermine their human rights, use them in the extreme or cruelly treat them. Of course, the Ethiopian criminal laws are very clear on issues of violence, crimes and maltreatments.

There is the need for community leaders and the government to legislate on the nature of Geta-Sratanya contract.

Governments should ensure that the country's laws on human rights, labour contracts and their like, the popular international conventions like United Nations Protocol to Prevent, Suppress and Punish Trafficking, Especially Women and Children, which was signed by over eighty nations in Palermo in 2000 and as a supplement of the UN Convention Against Transnational Organized Crime, etc, are enforced.

Both the Nigerian and Ethiopian Federal, State/Regional and Local Governments, as well as the community leaders, should initiate poverty alleviation programmes, and such should be devoid of inequity in income distribution and ensuring that the benefits of economic growth actually trickle down to the identified more vulnerable groups in the society. 
Perhaps, it was in recognition of this that past poverty alleviation policy interventions in Nigeria and other poor countries concentrated on low income individuals, groups, and communities particularly women, unemployed and marginalized rural and urban poor living below the FOS' accepted poverty line and lacking basic infrastructure and welfare services (Odejide, 1997; Edoh, 2003; Omudia, 2005).

\section{References:}

Abdullahi M., (1990 ) ed., Arewa House World Conference on Slavery and Society in History. Centre for Research and Historical Development, A.B.U. Kaduna, Lugard Hall, $26^{\text {th }}-30^{\text {th }}$ March, 1990

Abel Smith, B and P. Townsend (1965). The poor and the Poorest. Bell, London

Agbu, O. (2003). "Corruption and human trafficking: the Nigerian case." West African Review. African Resource Centre, Inc.

Aghatise, E. (2004, October). "Trafficking for prostitution in Italy: possible effects of government proposals for legalization of brothels." Violence Against Women 10(10).

Ahmad, E. (1981). The distribution of rural income in Pakistan: the incidence Inequality. University of Warwick Discussion Paper No.3 (September).

Aigbokhan, B.E. (1998). "Poverty, alleviation in Nigeria: some macroeconomic issues." Poverty alleviation in Nigeria. Ibadan: Nigerian Economic Society (NES), pp 181-209. 
Saratanya in Ethiopia \& 'Ya'yan Magajiya in Nigeria

Aita, J. (2004, March 5). "Effort to combat human trafficking increasing, U.S. official says" The United States Diplomatic Mission to Nigeria Press Release, Lagos-Nigeria.

Aku, P.S., M.J. Ibrahim and Y.D. Bulus (1997). "Perspectives on poverty and poverty alleviation strategies in

Nigeria." Poverty alleviation in Nigeria. Ibadan: Nigerian Economic Society (NES), pp 41-54.

Anyanwu J. C. (1997), "Poverty in Nigeria, concepts,

Measurement and Determinants'. Selected papers for

the 1997 annual Conference on poverty alleviation in

Nigeria, Nigerian Economic Society, 1997.

Aluko S. A. (1975). Poverty; Its Remedies". Poverty in

Nigeria, Proceedings of the 1975 Annual Conference of the Nigerian Economic Society, Ibadan.

Amis, P. and C. Rakodi (1994). "Urban poverty: issues for research and policy." Journal of International Development 6(5), pp 627-634.

Batchelder A. B. (1971), The Economics of Poverty, John Wiley, New York.

Beckerman, W (1979 a). The Impact of Income Maintenance

Programmes on Poverty in Four Development

countries ILO, Geneva.

Best, E.G. (2005). "Another Look at Gender Equality." Journal of Family Development 2(1): 340-346.

Blackwood, D.L. and R.G. Lynch (1994). "The measurement of inequality and poverty: a policy makers' guide to the literature." World Development 22(4): 567-578.

Canagarajah, S. et. al. (1995). Nigeria: poverty assessment document. World Bank: West African Region (July).

CBN (1998). Measuring and monitoring poverty in Nigeria. $7^{\text {th }}$ Annual Conference Proceedings. Abuja: Central Bank of Nigeria.

Chenery, H. et. al. (1979). "Growth and poverty in developing countries." In H.B. Chenery (ed), Structural changes 
and development policy. London: Oxford University Press.

Chete, L.N. and F.O. Roberts (1996), "Government and the economy: review of concepts and perspectives on Nigeria's political economy." NES Annual Conference Proceedings, pp 473-490.

Cowell, F. (1977). Measuring inequality. London: Philip Allan. Douglas, M, A. Botti and I. Guest (2000). "Trafficking in

women and girls."

http://www.peace.ca/traffickinginwomenand girls.htm.

Edoh, T. (2003). "Poverty and the survival of democracy in Nigeria." Nigerian Journal of Political and Administrative Studies 1 (4).

Farley, M. (2004). "'Bad for the body, bad for the heart": prostitution harms women even

if legalized or decriminalized." Violence Against Women, 10(10), Oct., pp $1087-1125$.

Fields, G. S. (1980), Poverty, Inequality and Development

University Press, Cambridge.

Filaba M. A., (2004) "Slavery and Slave Trade: Ageless and Nebulous Syndrome of Servitude and Commerce in Central Nigeria." Unpublished.

(2007) "Saratanya (House Servant) Culture in Jimma Town, Ethiopia, Compared to Similar Institutions and their Criminal Implications." Paper presented at the Staff Research Symposium, Research and Publication Office, Jimma University, July 12th 2007.

Fyfe, C. (1972). "Reform in West Africa: the abolition of the slave trade." Ajayi, J.F.A and M. Crowder (eds.) History of West Africa. London: Longman Group, pp $30-56$. 
Saratanya in Ethiopia \& 'Ya'yan Magajïya in Nigeria

Foster, J., J. Greer and E. Thorbecke (1984). "A class of decomposable poverty measures." Econometrica 52(3): 761-766.

Green Ward et al; Issue of Poverty in Nigeria Journal of

Economics and Social Studies Vol. 1 No. 3: 1994.

http://news.bbc.co.uk/go/pr/fr//1/hi/programmes/from our o wn correspondent/3632203.stm

http://www.voanews.com/english/archives/2005-03/2005-03-

24-voa57.cfm

Hynes, H.P. and J.G. Raymond (2002). "Put in harm's way: the neglected health consequences of sex trafficking in the United States." Silliman, J. and A. Bhattacharjee (eds.). Policing the National Body: Sex, Race, and Criminalization. Cambridge, Massachusetts: South End Press.

Inikori J. E., Forced Migration: The Impact of the Export Slave Trade on African Societies. Hutchinson Uni. Lib. For Africa. Hutchinson Publ. Group Ltd. The Anchor Press Ltd G. Britain, 1982.

Internet, (accessed 2007) Dictionary.com Unabridged (v 1.1) Random House Unabridged Dictionary, (C) Random House, Inc. 2006; Online Etymology Dictionary, (C) 2001 Douglas Harper WordNet The American Heritage $\mathbb{R}$ Dictionary of the English Language, Fourth Edition Copyright (c) 2000 by Houghton Mifflin Company Published by Houghton Mifflin Company

Jõe-Cannon, I. (ed.) \& J. Raymond and B. Kryszko (2006). Primer in the Male Demand for Prostitution. Massachusetts: N. Amherst.

John H. Conceptual and methodological Issues or Poverty

C.B.N. Publication (Bullion) October/December 1999. Little, A. (2004). "Nigeria's 'respectable' trade." BBC News broadcast on Saturday,

17 April, 2004 at 1130 BST on BBC Radio 4. 
Lovejoy P. S., Transformation on Slavery: $\underline{A}$ History of Slavery in Africa. African Studies Series, Cambridge University Press (Printed by Syndicate of Cambridge) 1983

Lovejoy P. E. and Jan S. Hogendorn, (1997) Slow Death for Slavery: The Course of Abolition in Northern Nigeria, 1897-1936 Cambridge University Press (Printed by Syndicate of Cambridge).

Mangvat M. Y., (1990) "Slaves and Slavery on the Jos Plateau in the $11^{\text {th }}$ century: A Review of Evidence." In Abdullahi M.

Mazrui A. A., (1990) "Comparative Slavery and African Triple Heritage: Indigenous, Islamic and Western Systems." In Abdullahi M.

NewVOA.com (2005). Human trafficking.

Olateru-Olagbegi, B. (2004). "Brief overview of the situational analysis of human trafficking in West Africa." Paper presented at the Seventh African Regional Conference on Women: Decade Review of the Implementation of the Dakar and Beijing Platforms for Action held in Addis Ababa, October 6 - 10.

NES (1975), Poverty in Nigeria. Annual Conference Proceedings. Ibadan:

Nigerian Economic Society.

(1997). Poverty Alleviation in Nigeria. Annual Conference Proceedings, Ibadan: Nigerian Economic Society.

Obadan, M.I. (1997). "Analytical framework for poverty reduction: issues of economic growth versus other strategies." Poverty Alleviation in Nigeria. Ibadan: Nigerian Economic Society (NES), pp 1-18. 
Saratanya in Ethiopia \& 'Ya'yan Magajiya in Nigeria

Odejide, A.F. (1997). "Breaking the vicious circle of poverty among women in developing countries: the case for micro-credit." Poverty Alleviation in Nigeria. Ibadan: Nigerian Economic Society (NES), pp 367-382.

Ogwumike, F.O. (1991). A basic needs oriented approach to the measurement of poverty in Nigeria. Nigerian Journal of Social and Economic Studies (NJESS), (33) 2: 105-120.

Ogwumike, F.O. and D.B. Ekpenyong (1996). "Impact of structural adjustment programme on policies on poverty in Nigeria." Research Report Submitted to AERC, Nairobi.

Okpeh, O.O.J. (2005). "The rural women and the women empowerment question in Nigeria: a refelection on some issues." African Journal of Environmental Law and Development Studies 1 (1): 85-98.

Omodia, S. (2005). "Poverty alleviation in a deregulated economy: challenges and prospects for sustainable democracy on Nigeria." Nasarawa University Journal of Administration, 2(1).

Onah, F.E. (1996). "Post adjustment policies towards poverty alleviation in Nigeria." Nigerian Journal of Economic and Social Studies 38 (1, 2, 3): 187-218.

Pereira, C. (2001). "Introduction to gender studies: an overview of concepts." Social Science Academy of Nigeria (May).

Schubert, R. (1994). "Poverty in developing countries: its definition, extent and implications." Economics 49/50: 17-40.

Sen, A.K. (1981). Poverty and families: an essay on

entitlement and deprivation. Oxford: Clarendon Press.

The World Bank (1990), World Development Report, Oxford

University Press. 
(1995) The Social impact of Adjustment Operation, OUP.

Todaro, M. P. 91985), Economic Development in the Third World. Longman. New York \&.

Ibrahim UMARU and Theophilus D. LAGI and Sam B.A. TENDE (2005) 'Women Trafficking and the 'Magajiya System' in Northern Nigeria: A Preliminary Survey of Truckers Transit Camps, Brothels and Other Conduits." Unpublished.

The Economist, (2004). "Nigeria's other export." April 22. http://www.economist.com.

ThisDay (2004). "Human trafficking: Nigeria raising stakes against offenders.

Nigeria: Global News Digest/IMDiversity.com.

TIMIDRIA NGO, "Slave Liberation Cancelled in Niger." Nigeria Wed. March 9 2005, p.14.

UNAIDS/WHO (2004). "Epidemiological on HIV/AIDS and sexually transmitted infections." 2004 Update, http://ww.unaids.org.

vonHauff, M. and B. Kruse (1994). "Conceptual bases for a logical poverty-oriented policy." Economic 49/50: 4155.

World Bank (1993). Poverty reduction handbook. Washington D.C.: World Bank. 
Saratanya in Ethiopia \& 'Ya'yan Magajiya in Nigeria

(1996). Nigeria: poverty in the midst of plenty, the challenge of growth with inclusion. Washington D.C.: World Bank.

(2003). Nigeria, poverty-environment linkages in the national resource sector. Washington D.C.: World Bank.

(2005). African Development Indicators.. Washington D.C. World Bank, pp 307.

Wright R. D., "Slavery in Africa." Microsoft $\mathbb{R}$ Encarta $(\mathbb{R}$ Encyclopaedia 2002. (C) 1993-2002 Microsoft Corp.WWW Microsoft. 